\title{
Effect of colchicine on the endochondral ossification of the epiphyseal cartilage of rat tibia
}

\author{
Eiichi Kubomura \\ Department of Pharmacology, Faculty of Dentistry, Tokyo Medical and Dental University \\ 5-45, Yushima, 1-chome, Bunkyo-ku, Tokyo 113 \\ (Chief: Prof. H. Ogura)
}

[Accepted for publication: September 20, 1984]

Key words: colchicine / autoradiography / epiphyseal cartilage / endochondral ossification

\begin{abstract}
A histological study and an autoradiographic study using tritiated thymidine were carried out to investigate the effect of colchicine on the epiphyseal growth cartilage of rat tibia, especially in relation to the function of microtubules.

Intravenous injection of colchicine $(1.0 \mathrm{mg} / \mathrm{kg})$ thickened the growth plate during the period from 3 to 5 days after administration. This was mainly due to an increase in number of hypertrophied chondrocytes. During the same period, the osteoblasts and the osteoclasts were detached from the trabecular bone at the junction of growth plate and metaphysis. The invasion of capillaries to the open end lacunae of the growth plate decreased remarkably $(P<0.01)$. Appearance of thin trabecular bones in the metaphysis was noted.

Autoradiographic study showed that following a decrease in number of labeled proliferative chondrocytes during the period from 2 to 8 hours after the colchicine administration, the number of labeled chondrocytes increased remarkably $(\mathrm{P}<0.01)$. Labeled osteoprogenitor cells at the junction of growth plate and metaphysis decreased $(\mathrm{P}<0.01)$ at $3-5$ days after colchicine administration.

At 6-10 days after administration, the thickness of the growth plate began to decrease with continuous erosion of the calcified cartilage septa. The invasion of capillaries to the growth plate was restored gradually and then osteoblasts and osteoclasts reappeared on the surface of spongiosa. The number of labeled osteoprogenitor cells and proliferative chondrocytes returned to a normal level.

These results suggest that colchicine treatment induced the synchronization of mitosis of proliferative chondrocytes in the growth plate. At the same time, colchicine treatment retarded the erosion of calcified cartilage matrix at the junction of growth plate and metaphysis and reduced the bone remodeling process of spongiosa which may have caused the increase in thickness of the growth plate.

These actions of colchicine may be closely related to the inhibition of microtubular function of cells engaged in the process of endochondral ossification.
\end{abstract}

\section{Introduction}

Endochondral ossification is a highly integrated process which is regulated by mechanical (Myers and Mow ${ }^{1)}$ ), hormonal $\left(\right.$ Silbermann $^{2)}$ ) and chemical (Ornoy and Zusman $^{3)}$ ) factors. The growth of bone is performed by the systematic sequence of proliferation and differentiation of cartilage cell, rapid matrix formation, and matrix mineralization (Bloom and Fawcett ${ }^{4}$, $\mathrm{Ali}^{5}$ ).
Many types of drugs affect the process of endochondral ossification, e.g., diphosphonate (Schenk et al. ${ }^{6)}$, Miller and $\mathrm{Jee}^{7)}$ ), strontium $\left(\right.$ Engferdt $\left.^{8)}\right)$, Vitamin D (Miller et al. ${ }^{9)}$, Silbermann et al. ${ }^{10)}$, Plachot et al. ${ }^{11)}$ ), warfarin $\left(\right.$ Price $\left.^{12)}\right)$ and salicylate $\left(\right.$ Futami $\left.^{13)}\right)$. These drugs have revealed the positive or negative effects on the sequential processes of cartilagenous mineralization, resorption of cartilage column and remodeling of spongiosa showing the characteristic morphological alteration of the long bone. 
Colchicine is known to be one of the agents which binds tightly to the microtubule component, tubulin and thus disrupts the microtubule (Borisy and Taylor ${ }^{14,15)}$ ). Using this specific action of colchicine, the function of the microtubules has been studied, and they included the chromosome movement to the pole during cell division cycle, the intracellular transport of materials, the development and the maintenance of cell shape, and the cellular motility (Dustin ${ }^{16)}$ ). By using electron microscopy, microtubules were found in the cells which were engaged in the process of endochondral ossification, such as chondrocyte (Lohmander et al. ${ }^{17)}$, Moskalewski et al. ${ }^{18)}$, Moskalewski, Thyberg and Friberg ${ }^{19)}$ ), osteoblast (Thyberg, Moskalewski and Friberg ${ }^{20)}$, $\mathrm{Ohya}^{21)}$ ) and osteoclast (Holtrop, Raisz and Simmons ${ }^{22)}$ ).

It has been revealed that colchicine inhibits the secretion of proteoglycans in chondrocytes by blocking the function of Golgi complex in which the secretory products are condensed and packed. This leads the retardation of the synthesis and the secretion of proteoglycans from chondrocytes (Lohmander et al. ${ }^{17)}$, Moskalewski et al. ${ }^{18)}$, Takano et $a l^{23)}$ ). Similar effects of colchicine were reported in the matrix secretion of osteoblasts (Ehrlich and Bornstein ${ }^{24)}$, Scherft and Heershe ${ }^{25)}$, Ohya $\left.{ }^{21)}\right)$. Osteoclasts in culture were also inhibited in their bone resorbing activity by the colchicine treatment through its inhibitory effect on ruffled border (Holtrop, Raisz and Simmons ${ }^{22)}$ ). From these studies, microtubule seems to be important in both matrix formation and resorption of the hard tissue.

The purpose of the present study was to investigate the effect of colchicine on the epiphyseal growth cartilage of rat tibia and to elucidate the role of the microtubule in the process of endochondral ossification by the histological and the autoradiographic studies.

\section{Materials and Methods}

One hundred and thirty seven male Wistar rats aged six weeks were used in the experiments.

\section{Histological study}

Rats were injected once intravenously with an aqueous solution ( 0.1 per cent) of colchicine (Merck Co. Darmstadt, West Germany) at a dose of $1 \mathrm{mg}$ per kilogram of body weight. Rats in the control group were injected intravenously once with an equivalent volume of physiological saline.

Rats were killed by cervical dislocaiton at intervals each day from 1-10 days after the colchicine injection and rats in control groups were killed at 7 days and 10 days respectively.

Tibiae were removed and fixed in phosphate-buffered glutaraldehyde-formalin solution adjusted to $\mathrm{pH} 7.2$ (Reese and Karnov$\mathrm{sky}^{26)}$ ) for one week at $4^{\circ} \mathrm{C}$. For the light microscopic study, they were demineralized with 10 per cent EDTA ( $\mathrm{pH}$ 7.2) for two weeks. After dehydration in ethanol, tibiae were embedded in glycol-metacrylate resin (GMA, Nissin EM, Tokyo). The specimens were cut longitudinally at a mid-sagittal plane in $2 \mu \mathrm{m}$ thickness and the sections were stained with azure-eosin (Bennet et al. ${ }^{27)}$ ). For the histochemical observation, some sections were stained with alcian blue or Schiff's reagent for the periodic acid-Schiff (PAS) reaction. For the contact microradiographic (CMR) study, tibiae were dehydrated in ethanol after fixation and embedded in Rigolac (polyester resin, Nissin EM, Tokyo). Ground sections were obtained from the midsagittal plane of tibiae. The sections, $80 \mu \mathrm{m}$ in thickness, were prepared using Isomet (Buehler Ltd. U.S.A.) followed by manual grinding. Contact microradiographs were made with Kodak 649-0 films (Eastman Kodak, Rochester, U.S.A.) using a microradiographic apparatus (Softex Type-CMR, Softex, Tokyo) at $7 \mathrm{kV}$ and $3 \mathrm{~mA}$ for 15 minutes.

Number of rats in light microscopic study and CMR study was 8 and 5 respectively.

\section{Autoradiographic study}

The procedure of drug administration to the rats were the same as in the histological study except for isotope administration. Rats were injected intraperitoneally once with 0.1 $\mu \mathrm{Ci}$ of tritiated thymidine (Specific Activity 
24.5 Ci per mmole, Amersham, Japan) per gram body weight at 2 hours before killing except for background group. Eight rats of each group were killed by the same method used in the histological study at 2, 4, 8 and 12 hours and 1, 2, 3, 4, 5, 6, 8 and 10 days after colchicine administration. Rats in control and background groups were killed by the same method after 10 days.

Tibiae were fixed, demineralized and embedded as described in the light microscopic study. The sections cut in $2 \mu \mathrm{m}$ thickness were dipped in autoradiographic emulsion (SAKURA NR-M2, Konishiroku Co. Tokyo) at $40^{\circ} \mathrm{C}$, allowed to dry a few hours at $20^{\circ} \mathrm{C}$, placed in black Bakelite boxes and exposed at $4^{\circ} \mathrm{C}$ for eight weeks. Sections were developed (SAKURA, KONIDOL-X), fixed (SAKURA, KONIFIX), rinsed with distilled water and stained with azure-eosin.

Labeled cells were defined to be those which had ten or more grains in a nucleus.

\section{Schematic illustration of counted area of labeled cells}

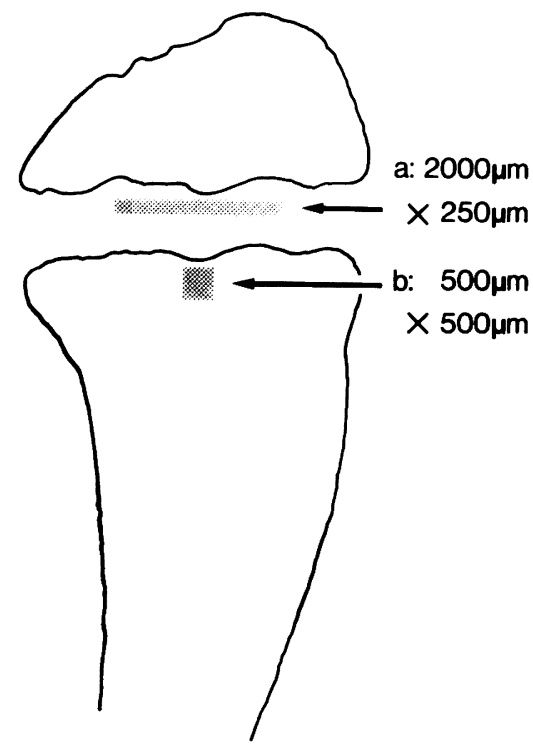

Fig. 1 Schematic illustration of the counted area of tritium-labeled proliferative chondrocytes $(\mathrm{a}:$ in the rectangle of $2500 \mu \mathrm{m} \times 250 \mu \mathrm{m})$ and osteoprogenitor cells (b: in the square of 500 $\mu \mathrm{m} \times 500 \mu \mathrm{m})$.
The number of labeled proliferative chondrocytes was counted within the rectangle of $2000 \mu \mathrm{m} \times 250 \mu \mathrm{m}$ at the central portion of the horizontal length of epiphyseal growth plate and the number of labeled osteoprogenitor cells within the square of $500 \mu \mathrm{m} \times 500 \mu \mathrm{m}$ at the central portion at the junction of growth plate and metaphysis (Fig. 1). Identification of the osteoprogenitor cell was done according to the criteria of the previous study (Young ${ }^{28)}$, Kimmel and $\mathrm{Jee}^{29)}$ ).

Statistical analysis was performed by means of Student's $t$-test.

\section{Results}

\section{Growth}

The growth patterns of body weight and length of tibiae in control and colchicinetreated animals are shown in Fig. 2. Control animals exhibited a typical growth pattern. In the colchicine-treated animals, their increase in body weight depressed for 2 days and length of tibiae for 3 days after colchicine administration.

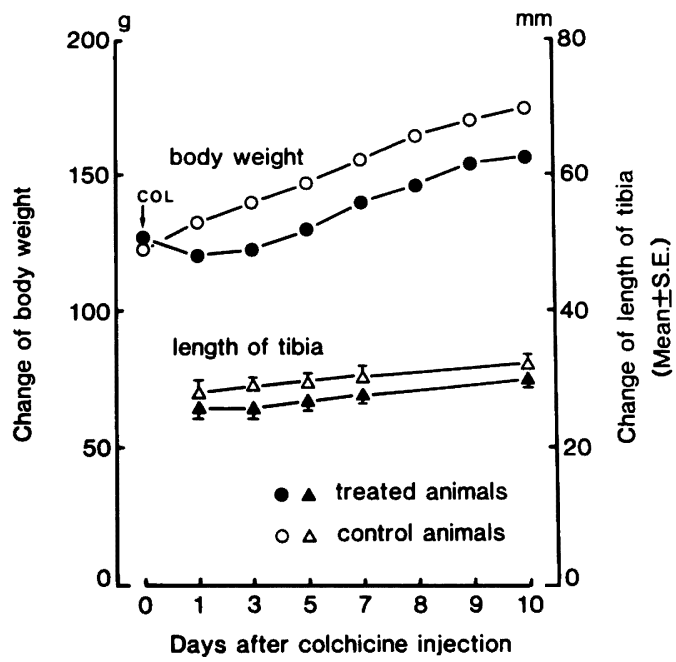

Fig. 2 Growth patterns of body weight and the length of tibiae in control and colchicine treated animals during experimental period. After colchicine administration, a temporary inhibition of body weight and length of tibia was noted. Values are the mean of 8 rats. 


\section{Histological observations}

1. GMR observations of calcified cartilage and metaphysis

At 3 days after colchicine administration, trabecular bones which were located in the primary and the secondary spongiosa became thinner and their number increased. Thickness of epiphyseal growth plate and provisional calcified matrix (PCM) expanded (Fig. 3). At 7 days after the colchicine injecton, calcified cartilage and metaphysis were almost the same as in the control animals.

\section{Light microscopic observation}

\section{a) Growth Plate}

The histological picture in azure-eosin stained section of the control animal showed four typical cartilage zones: (1) the resting zone in which immature chondrocytes were scattered sparingly in the intercellular matrix, (2) the zone of proliferating cells consisting of parallel columns of flattened cells, (3) the hypertrophic cell zone, and (4) the zone of provisional calcification, whose end was penetrated by capillaries from the metaphyseal bone marrow (Fig. 4a).

During 1-5 days after colchicine administration, thickness of the growth plate increased remarkably $(\mathrm{P}<0.001$; Fig. 5$)$. The shape of the proliferative chondrocytes became round and their number increased $(\mathrm{P}<$ 0.01 ; Fig. 5). The number of the hypertrophied chondrocytes also increased remarkably $(P<0.001$; Fig. 5$)$ and larger area of growth plate was occupied by the hypertrophied chondrocytes. Hypertrophied chondrocytes at the lower part of hypertrophic cell zone showed karyopyknosis. Their cell shapes changed to small and flattened ones compared with those of normal hypertrophied chondrocytes. However, in the upper part of the hypertrophic cell zone, the hypertrophied chondrocytes showed morphologically almost normal (Fig. 4c).

At 6 days after administration, hypertrophic cell zone still remained wide. However capillary invasions began to occur in some areas (Fig. 4e). At 10 days, the growth plate showed a morphologically normal appearance (Fig. 4g) and the thickness re- turned to the control level.

b) Junction of Growth Plate Cartilage and Metaphysis

The capillaries at the junction of growth plate and metaphysis enlarged and congested at 1-2 days after colchicine administration. Many osteoblasts and osteoclasts were detached from the calcified cartilage remnants. The spindle-shaped osteoblasts changed to those with flattened or rounded appearance with many cytoplasmic vacuoles.

At 3-4 days, the capillaries decreased in number and were scarcely found at the juncton of growth plate and metaphysis $(\mathrm{P}<0.01$, Fig. 6 and Fig. 4d). There were many unresorbed calcified cartilage remnants. Osteoblasts and osteoclasts which were stained weakly with azure-eosin were scattered in the bone marrow. Osteoid was not observed on the surface of calcified cartilage remnants.

At 6 days after administration, partial revascularization occurred and capillaries began to invade the end of growth plate. Osteoblasts and osteoclasts reattached to the calcified cartilage remnants and staining property of these cells were almost recovered, although irregular unresorbed cartilage remnants still remained. Osteoid reappeared on the surface of calcified cartilage matrix (Fig. 4f).

At 10 days after colchicine administration, the number of capillaries invading the growth plate was almost recovered to the normal level and cartilage resorbing cells began to erode the calcified cartilage septa. Calcified cartilage remnants were covered again with a layer of osteoblasts and osteoblasts (Fig. 4h).

\section{Autoradiographic observation}

1. Chondrocytes of Proliferative Zone

In a short period (2-8 hours) after colchicine administration, cells labeled with tritiated thymidine decreased in number remarkably $(\mathrm{P}<0.05)$. After that the number increased and reached the maximum at 3-4 days after colchicine administration $(\mathrm{P}<$ $0.01)$. The number of labeled cells were almost equal to that of the controls at $8-10$ days (Fig. 6). 


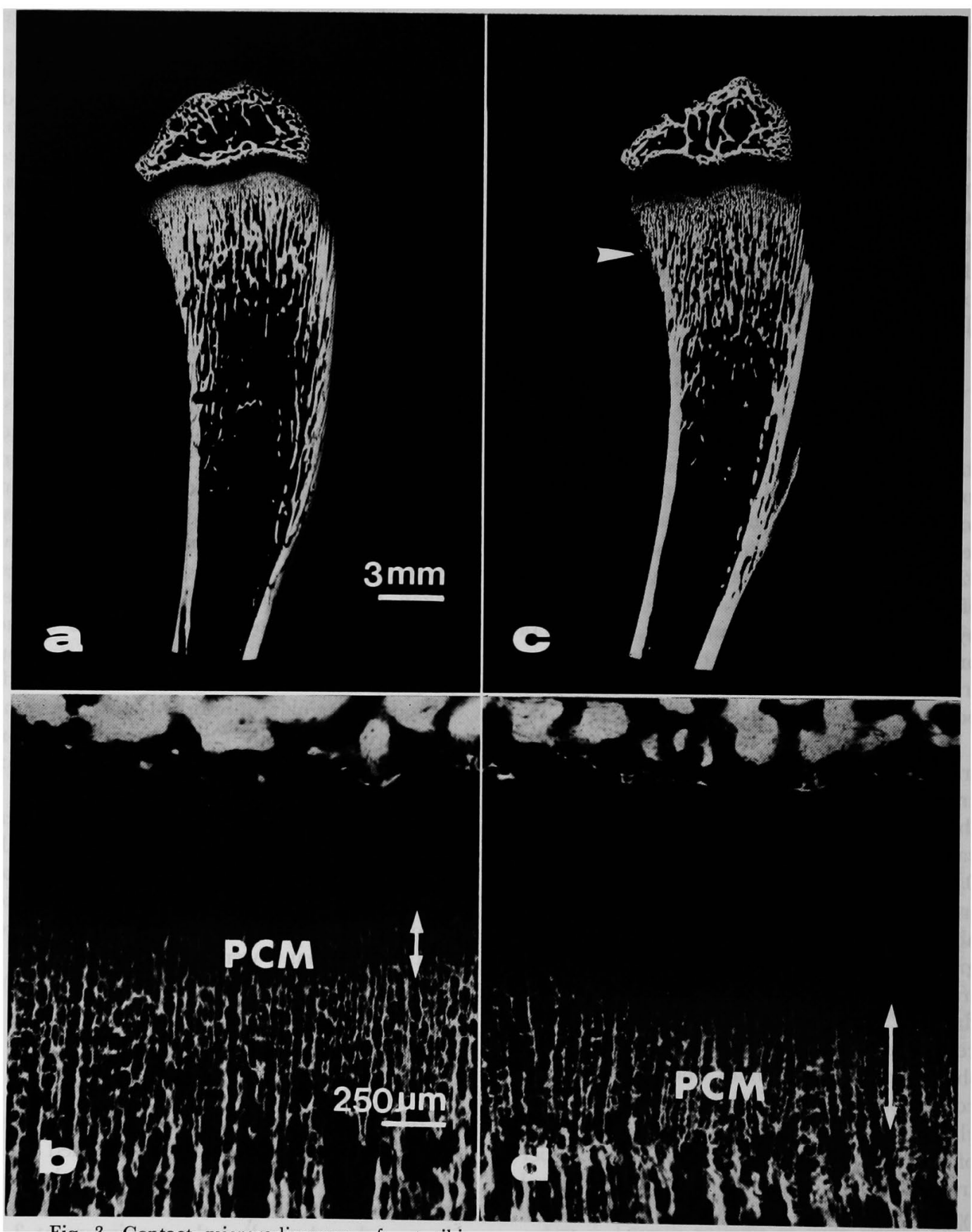

Fig. 3 Contact microradiograms of rat tibia.

a) and b): Control ( $\times 6$ and $\times 67$, respectively).

c) and $d)$ : Three days after the colchicine administration $(\times 6$ and $\times 67$, respectively). Thickness of epiphyseal growth plate and provisional calcified matrix (PCM) expanded and appearance of thin trabecular bones (arrow head) in the metaphysis are noted. 




Fig. 4 


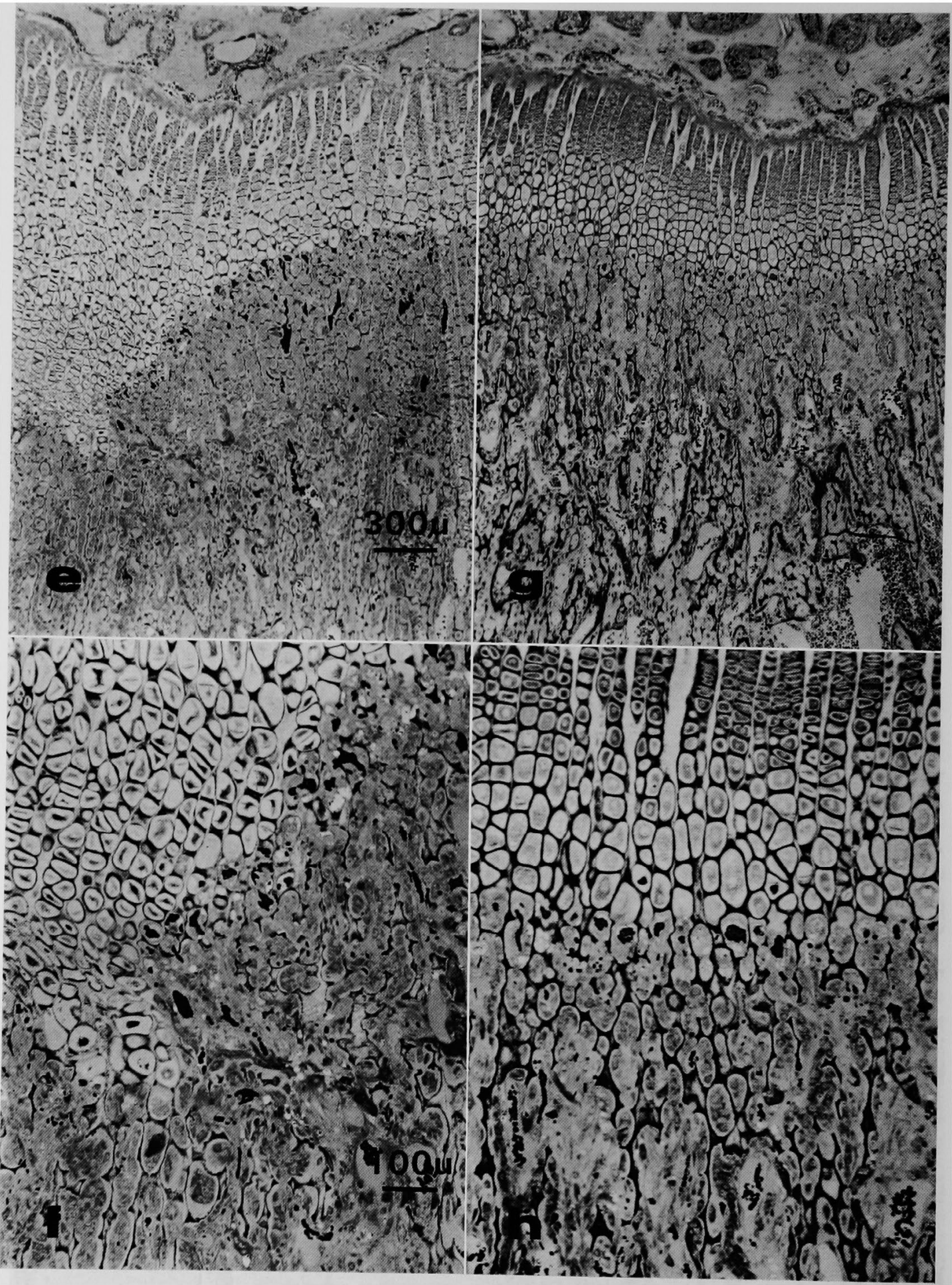

Fig. 4 


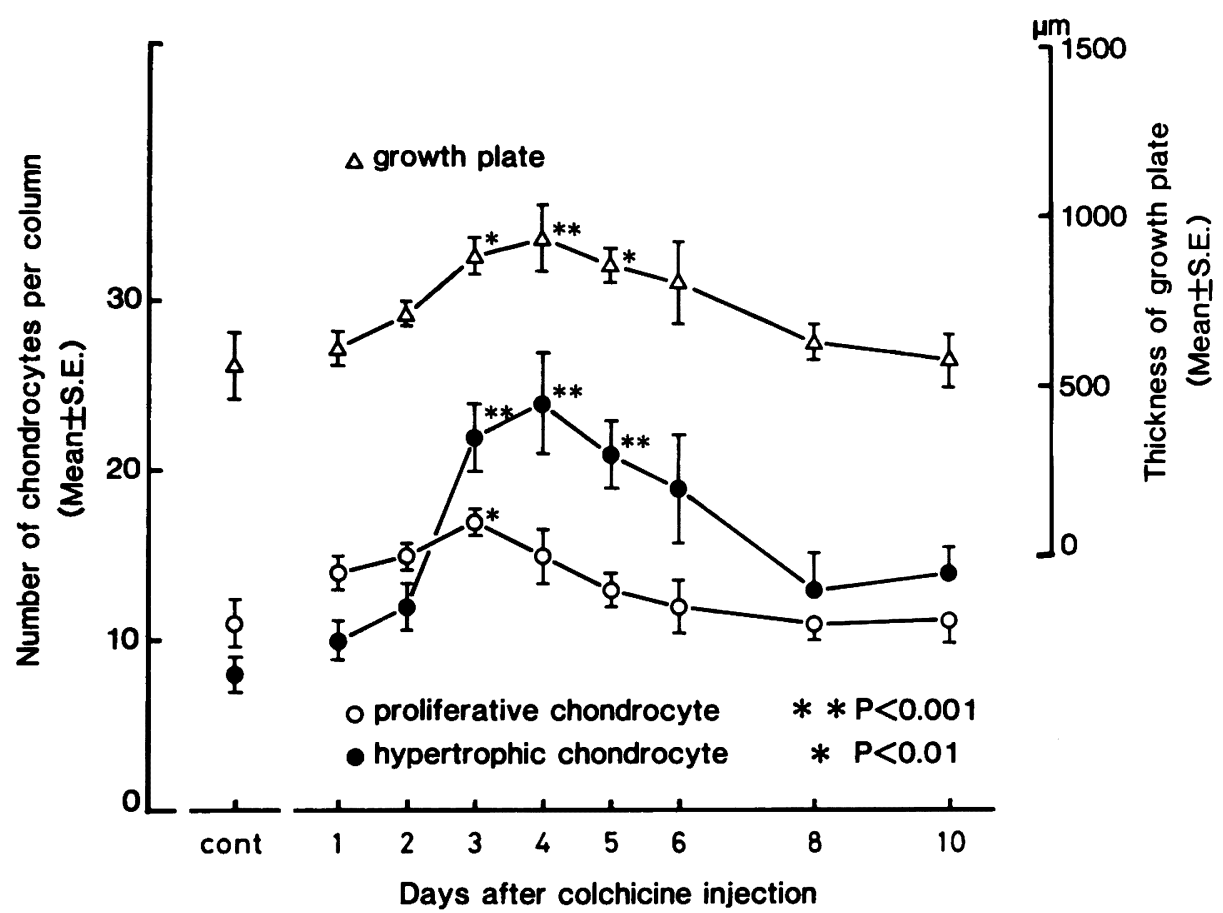

Fig. 5 Number of chondrocytes per column and the thickness of growth plate after colchicine administration. During 3-5 days after the administration, the number of proliferative chondrocytes, hypertrophied chondrocytes, and the thickness of growth plate increased. Values are the mean \pm S.E. of 8 rats.

2. Osteoprogenitor Cells at the Junction of Growth Cartilage and Metaphysis The number of labeled osteoprogenitor cells decreased $(P<0.01)$ at $3-5$ days after colchicine administration. After that, they increased gradually and returned to almost the same level as the controls at 8-10 days after colchicine administration (Fig. 6).

\section{Histochemical studies}

Histochemical reactions in the sections of tibiae in the control and the colchicinetreated animals were as follows:

Alcian Blue staining: A positive alcian blue reaction reveals the presence of acid mucopolysaccharides. In control animals, alcian blue staining reaction was seen in the

Fig. 4 The histological changes in growth plate cartilage of rat tibia. (Fig. a), c), e) and g): $\times 52$, Fig. b), d), f) and h): $\times 130$, respectively).

a) and b): Control. (GP: epiphyseal growth plate).

c) and d): Three days after the colchicine administration. Cartilage columns were broken to small fragments. Note the widened growth plate and increase in number of hypertrophied chondrocytes. The hypertrophied cells in the lower zone changed their shapes small and flat and showed karyophyknosis. The number of invading capillaries to the growth plate decreased remarkably.

e) and f): Six days after colchicine administration. Partially revascularization occurred and the capillaries began to invade to the end of the growth plate.

g) and $\mathrm{h}):$ Ten days after colchicine administration. The reappearance of normal shape of growth plate cartilage and the morphological characteristics of metaphysis almost recovered. 


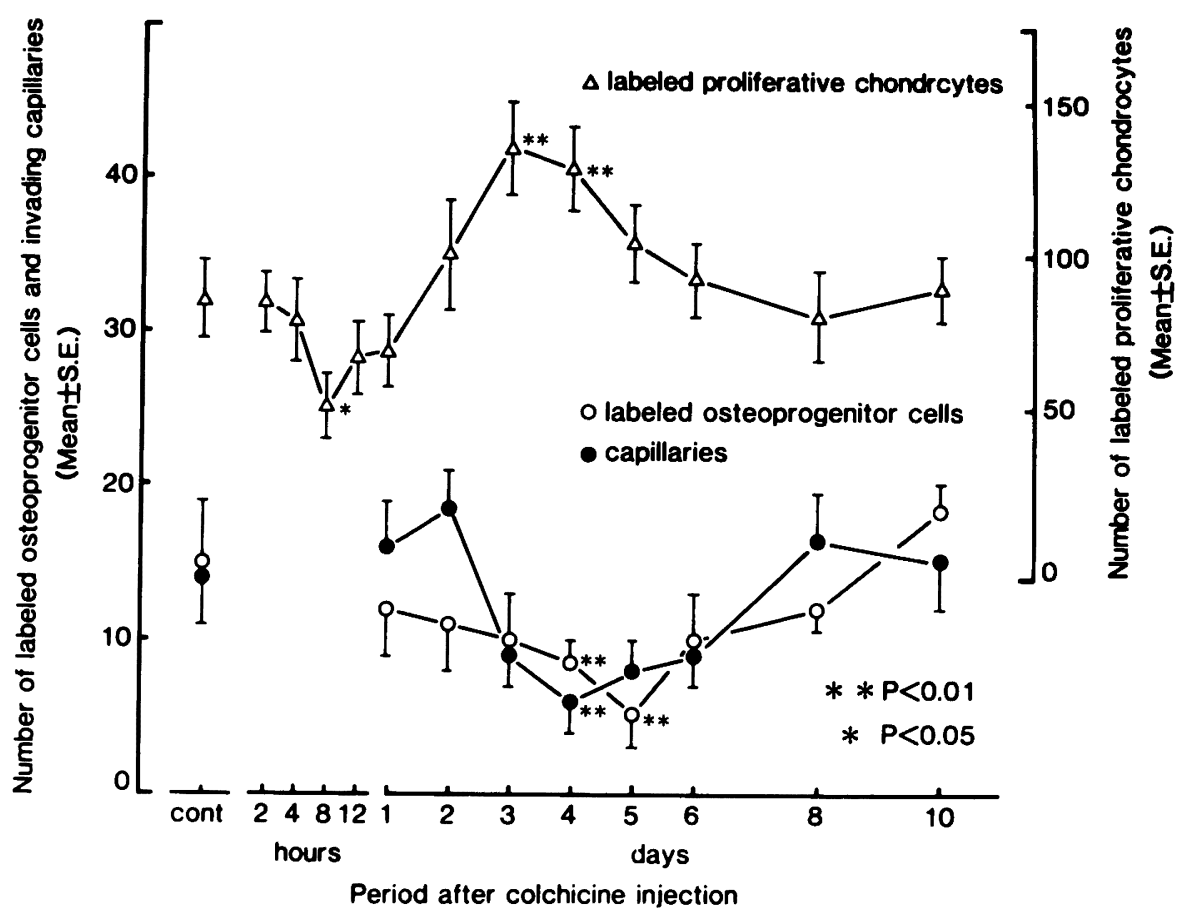

Fig. 6 Number of tritium-labeled proliferative chondrocytes, osteoprogenitor cells and invading capillaries to the growth plate. Explanation, see text.

Values are the mean \pm S.E. of 8 rats.

provisional calcifying zone of the growth plate. Staining reaction was reduced by the continual resorption of cartilage resorbing cells at the junction of growth plate and metaphysis, but some staining reaction still remained in primary spongiosa. On the other hand, alcian blue staining reaction was seen extensively even in the region of the primary spongiosa in metaphysis in colchicine-treated animals. The matrix of the increased hypertrophic cell zone was also stained positively with alcian blue (Fig. 7).

PAS reaction: PAS reaction in the tibiae of both control and colchicine-treated animals was almost equivalent to the alcian blue staining reaction.

\section{Discussion}

The observation of CMR and histological studies showed that thickness of the growth plate of proximal epiphyseal cartilage reached a maximum level, twice that of the control at 3 days after colchicine administration. This expansion of the growth plate was due to increase in the number of hypertrophic chondrocytes. This phenomenon may be caused at least by two different mechanisms.

First, synchrony of the cell cycle of proliferative chondrocytes was induced by colchicine. Colchicine is known to interrupt the mitotic process of proliferative chondrocytes by disturbing the microtubular function of spindle fiber and thus cell division was arrested in metaphase (Dustin ${ }^{16)}$ ). This was confirmed by the autoradiographic observation in the present study that proliferative chondrocytes showed a low tritiated thymidine uptake at 8 hours after colchicine administration (Fig. 6). After recovery from the effect of colchicine, chondrocytes in proliferative zone synchronized their cell cycle and proliferated together simultaneously, which was shown by an higher uptake of tritiated thymidine (Fig. 6). These cells began to secrete the extracellular matrix and 


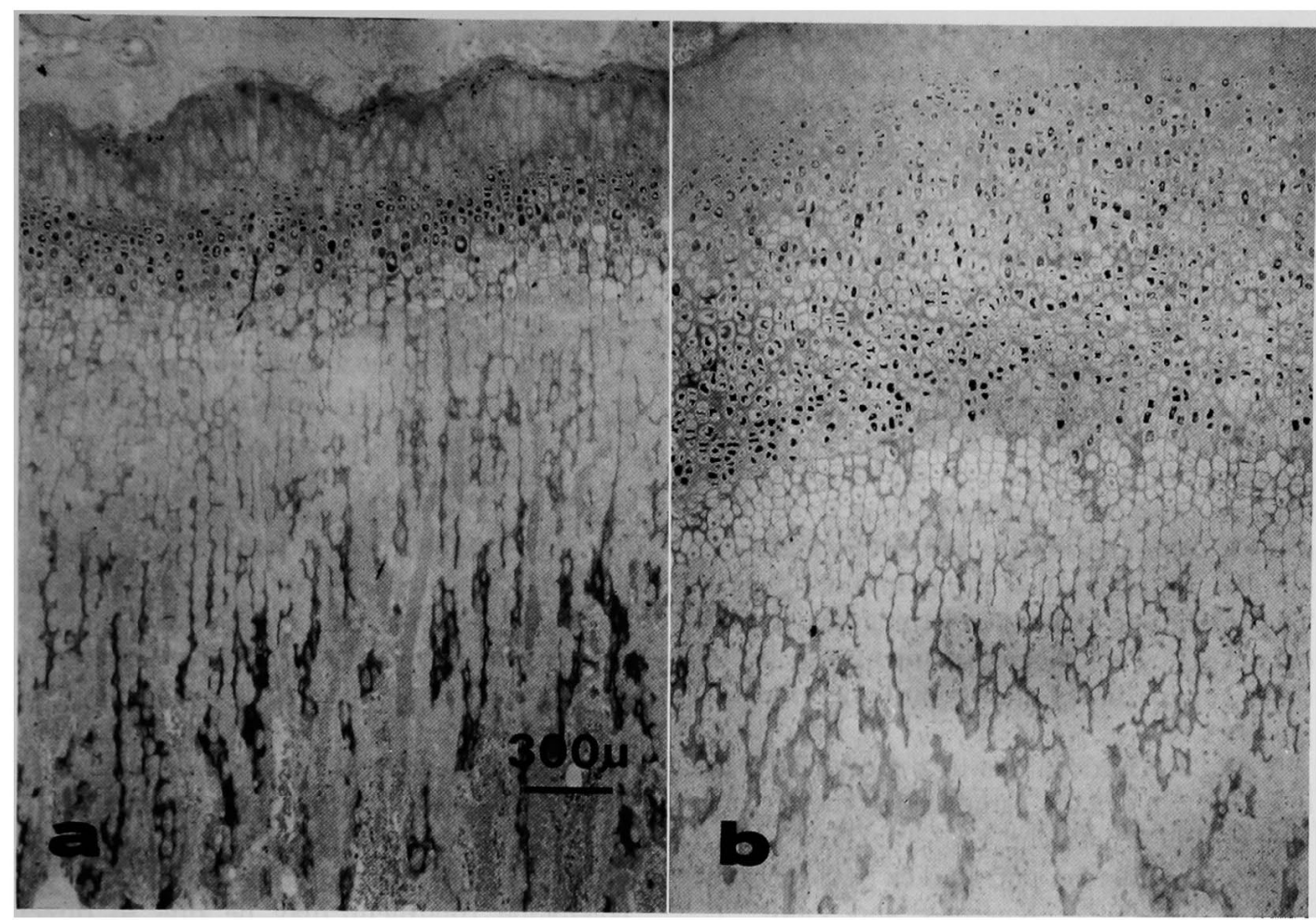

Fig. 7 Alcian blue stained sections of rat tibiae $(\times 50)$.
a) Control.
b) Three days after the colchicine administration.
Explanation, see text.

modulate their nature to hypertrophic chondrocytes. Consequently, hypertrophied chondrocytes increased their number and occupied a larger area of growth plate.

Second, erosion of calcified cartilage column by cartilage resorbing cells at the junction of growth plate cartilage and metaphysis was interrupted by colchicine. There exist many types of cells which resorbe calcified cartilage in this region, such as chondroclast, osteoclast, macrophage and perivascular cell (Schenk et al. ${ }^{30,31)}$ ). In the histological observation in the present study, the number of capillaries decreased and staining characteristics of osteoclasts were changed. Since the bone resorbing activity of osteoclasts is known to be reduced by colchicine treatment (Holtrop, Raisz and Simmons ${ }^{22)}$ ), cartilage resorbing activity of the cells at the site of cartilage destruction may be reduced by colchicine treatment. The dis- turbance of resorption of calcified cartilage resulted in an accumulation of hypertrophied chondrocytes in the growth plate.

The kinetic analysis of bone cells using tritiated thymidine by Kimmel and $\mathrm{Jee}^{32)}$ showed that there were two types of osteoprogenitor cells at the junction of growth plate and metaphysis; they are preosteoblast which migrates along the trabecular bone from the metaphysis, and preosteoclast which comes through the capillary to the end of the growth plate. Our autoradiographic study using tritiated thymidine showed that the number of labeled osteoprogenitor cells decreased during the period from 3 to 5 days after colchicine administration and did not increase until after 6 days. These findings indicate that the reduction of proliferation of bone cells at the region where the resorption of growth plate and bone remodeling of the spongiosa in metaphysis occur. 
From observation of the histochemical study in the metaphyseal region, the increase in number of alcian blue positive trabecular bone in the primary spongiosa suggested that bone remodeling at this region might have not occurred. It was confirmed by the CMR observation that the thinner trabecular bone increased in the metaphyseal region. The same phenomenon was also shown in rat metaphysis after injection of sodium salicylate (Futami ${ }^{13)}$ ) and diphosphonates (Schenk et al. ${ }^{6}$, Miller and $\left.\mathrm{Jee}^{7)}\right)$. These previous studies suggest that the drugs inhibit bone resorption at the primary and secondary spongiosa, which leads to an increase in number of trabecular bone in metaphysis. The inhibition of bone resorbing activity of osteoclasts by colchicine treatment may cause the accumulation of trabecular bone in metaphysis.

Vascular contribution to osteogenesis was observed in many studies (Trueta and Morgan $^{33)}$, Trueta and Little ${ }^{34)}$, Cameron ${ }^{35)}$, Irving $^{36)}$, Anderson and Parker ${ }^{37)}$, Schenk et $a ._{.}^{29,30)}$, Schenk ${ }^{38)}$, Kuettner and Pauli ${ }^{39)}$ ). They described that capillary invasion of the growth cartilage is a process necessary for endochondral ossification. Schenk ${ }^{37)}$ suggested that numerous cytoplasmic processes derived from the perivascular and/or endotherial cells penetrate and lyse the unmineralized transverse cartilagenous walls at the erosion zone and that microtubules are observed within the cytoplasm in the immediate vicinity of the cell process. Although the precise functions of microtubules in these cells are still unclear, colchicine may reduce the number of invading capillaries through destruction of microtubules in the perivascular and/or endothelial cells.

The number of invading capillaries decreased at 4 days after colchicine administration and labeled osteoprogenitor cells also decreased 1 day later in this period. In the recovery process, capillary invasion to the growth plate proceeded the increase of mitotic activity of osteoprogenitor cells (Fig. 6 ). These findings suggest that the mitotic activity of osteoprogenitor cells is closely related to capillary invasion and that vascular invasions are of considerable importance to the recovery process of endochondral ossification.

Colchicine inhibits the secretory mechanisms of cells by disturbing the function of microtubules, i.e., accumulation, package and transportation of the secretory products to the cell membrane for secretion. The secretory process of chondrocytes and osteoblasts was also inhibited by colchicine (Lohmander et al. ${ }^{17)}$, Moskalewski et al. ${ }^{18)}$, Ohya ${ }^{21)}$, Ehrlich and Bornstein ${ }^{24)}$, Scherft and Heershe $^{25)}$ ). Although the effect of colchicine on this process could hardly be evaluated in the present study, it is probable that chondrocytes in the growth plate and osteoblasts in metaphysis lose their secretory activities in the cartilage and bone matrix.

The present study showed that the disturbance of endochondral ossification by colchicine treatment may be due to direct and indirect action of colchicine on the epiphyseal cartilage and metaphyseal region. Colchicine disturbed the mitotic activity of the proliferative chondrocytes following excessive recovery of mitotic activity and also reduced the funtion of cartilage resorbing cells and bone cells at the metaphyseal site. These actions of colchicine may be closely related to inhibition of microtubular function of a cell engaged in the process of endochondral ossification.

\section{Acknowledgement}

The author is grateful to Professor H. Ogura for his continuous guidance and for many discussions and to Professor N. Tsuchida and Dr. K. Ohya for their valuable suggestions in preparing the manuscript. The author also wishes to thank Dr. S. Mataki and Dr. S. Kasugai for their kind assistance in carrying out the present study. 
抄録: Colchicine の骨端軟骨に及ぼす影響を, 組織学的並びに tritiated thymidine を用いた autoradiography による検索を行なった。

Colchicine を静脈内投与後， 3-5 日でラット脛骨の骨端成長軟骨板の厚さが増加した。骨端成長軟骨 板においては, 肥大軟骨細胞数の著しい増加が認められた。骨端成長軟骨板と骨幹端の接合部では, 一次 骨梁表面から骨芽細胞や破骨細胞が離れ, また骨端成長㳄骨板の終末部へ侵入する血管数も著しく減少し た。骨梁について見ると，骨幹端部において正常よりも細い骨梁の形成が認められた。Autoradiography による所見では, colchicine 投与後急速に増殖層の軟骨細胞の分裂活性が低下し, その後 3-4 日で著しい 分裂活性の増加を示したが，骨原性細胞の分裂活性はこの時期に低下寸る事が確かめられた。

Colchicine 投与後, 6-10 日で石灰化軟骨基質の破壊が骨端成長軟骨と骨幹端の接合部で始まると共に, 骨端成長軟骨への血管侵入数は増加し, 骨梁表面には骨来細胞や破骨細胞が再び現われ始めた。Tritiated thymidine で標識された骨原性細胞数は, この時期に正常レベルに復した。

これらの実験結果は, colchicine が骨端成長軟骨部で增殖層の軟骨細胞の分裂時期を同調させ, 一方骨 幹端部では石灰化軟骨基質の破壊を阻害し，その結果，骨端成長軟骨板の厚さが増加した事を示してい る。また, colchicine は骨梁における骨改造を抑制する事も明らかにされた。

これらの事実から, 軟骨内骨化の過程を抑制する colchicine の作用は, その過程に関与している練胞 群における微小管機能の抑制と密接に関係しているものと考えられる。

\section{References}

1) Myers, E. R. and Mow, V. C.: Biomechanics of cartilage and its response to biomechanical stimuli. In: Cartilage (Hall, B. K., ed.), vol. 1, pp. 313-341, Academic Press, New York, 1983.

2) Silbermann, M.: Hormones and cartilage. In: Cartilage (Hall, B. K., ed.), vol. 2, pp. 327-368, Academic Press, New York, 1983.

3) Ornoy, A. and Zusman, I.: Vitamins and cartilage. In: Cartilage (Hall, B. K., ed.), vol. 2, pp. 297-326, Academic Press, New York, 1983.

4) Bloom, W. and Fawcett, D. W.: Bone. In: Histology, 10th ed., pp. 244-287, Saunders, Philadelphia, 1975.

5) Ali, S. Y.: Calcification of cartilage. In: Cartilage (Hall, B. K., ed.), vol. 1, pp. 343378, Academic, New York, 1983.

6) Schenk, R., Merz, W. A., Russel, R. G. G., Muhlbauer, R. C. and Fleisch, H.: Effect of ethan-1-hydroxy-1,1-diphosphonate (EHDP) and dichloromethylene diphosphonate $\left(\mathrm{Cl}_{2-}\right.$ MDP) on the calcification and resorption of cartilage and bone in the tibial epiphysis and metaphysis of rats. Calcif. Tiss. Res. 11: 196-214, 1973.

7) Miller, S. C. and Jee, W. S. S.: Ethan-1hydroxy-1,1-diphosphonate (EHDP) effects on growth and modeling of the rat tibia. Calcif. Tiss. Res. 18: 215-231, 1975.

8) Engferdt, B. and Hjertquist, S. O.: The effect of strontium administration on bones and teeth of rats maintained on diets with different calcium contents. Virchows Arch. A Path. Ana. 346: 330-344, 1969.

9) Miller, S. C., Halloran, B. P., DeLuca, H. F., Yamada, S., Takayama, H. and Jee, W. S. S.: Studies on the role of 24-hydroxylation of Vitamin D in the mineralization of cartilage and bone of Vitamin D-deficient rats. Calcif. Tiss. Int. 33: 489-497, 1981.

10) Silbermann, M., Mirsky, N., Levitan, S. and Weisman, Y.: The effect of 1,25-dihydroxyvitamin $\mathrm{D}_{3}$ on cartilage growth in neonatal mice. Metab. Bone Dis. \& Rel. Res. 4: 337-345, 1983.

11) Plachot, J. J., DuBois, M. B., Halpern, S., Witmer, G. C., Garabedian, M. and Balsan, $\mathrm{S}$ : : In vitro aciton of 1,25-dihydroxycholecalciferol and 24,25-dihydroxycholecalciferol on matrix organization and mineral distribution in rabbit growth plate. Metab. Bone Dis. \& Rel. Res. 4: 135-142, 1982.

12) Price, P. A., Williamson, M. K., Haba, T., Dell, R. B. and Jee, W. S. S.: Excessive mineralization with growth plate closure in rats on chronic warfarin treatment. Proc. Natl. Acad. Sci. USA 79: 7734-7738, 1982.

13) Futami, K.: Inhibition of bone growth by sodium salicylate. Bull. Tokyo Med. Dent. Univ. 20: 303-322, 1973.

14) Borisy, G. G. and Taylor, E. W.: The mechanism of action of colchicine $-{ }^{3} \mathrm{H}$ to cellular protein. J. Cell Biol. 34: 525-533, 1967.

15) Borisy, G. G. and Taylor, E. W.: The 
mechanism of action of colchicine. Colchicine binding to sea urchin eggs and mitotic apparatus. J. Cell Biol. 34: 535-548, 1967.

16) Dustin, P.: Microtubules, 1st ed., Springer, Berlin, 1978.

17) Lohmander, S., Moskalewski, S., Madsen, K., Thyberg, J. and Friberg, U.: Influence of colchicine on the synthesis and secretion of proteoglycans and collagen by fetal guinea pig chondrocytes. Exp. Cell Res. 99: 333345, 1976.

18) Moskalewski, S., Thyberg, J., Lohmander, S. and Friberg, U.: Influence of colchicine and vinblastine on the Golgi complex and matrix deposition in chondrocyte aggregates. Exp. Cell Res. 95: 440-454, 1975.

19) Moskalewski, S., Thyberg, J. and Friberg, U.: Cold and metabolic inhibitor effects on cytoplasmic microtubules and the Golgi complex in cultured rat epiphyseal chodrocytes. Cell Tiss. Res. 210: 403-415, 1980.

20) Thyberg, J., Moskalewski, S. and Friberg, U.: Effects of antimicrotubular agents on the fine structure of the Golgi complex in embryonic osteoblasts. Cell Tiss. Res. 193: 247-257, 1978.

21) Ohya, K.: Effects of colchicine on osteoblast in rat. Bull. Tokyo Med. Dent. Univ. 25: 277-295, 1978.

22) Holtrop, M. E., Raisz, L. G. and Simmons, H. A.: The effects of parathyroid hormone, colchicine, and calcitonin on the ultrastructure and the activity of osteoclasts in organ culure. J. Cell Biol. 60: 346-355, 1974.

23 ) Takano, T., Takigawa, M., Shirai, E., Sakuda, M. and Suzuki, F.: Cytoskeleton and differentiated phenotype of chondrocytes in culture. -Effects of cytochalasin B and colchicineJpn. J. Bone Metab. 2: 192-199, 1984.

24) Ehrlich, H. P. and Bornstein, P.: Microtubules in transcellular movement of procollagen. Nature (London) New Biol. 238: 257-260, 1972.

25) Scherft, J. P. and Heershe, J. N. M.: Accumulation of collagen-containing vacuoles in osteoblasts after administration of colchicine. Cell Tiss. Res. 157: 353-365, 1975.

26) Reese, T. S. and Karnovsky, M. J.: Fine structural localization of blood-brain barrier to exogenous peroxidase. J. Cell Biol. 34: 207-217, 1967.

27) Bennet, H. S., Wyrick, A. D., Lee, S. W. and NcNeil, J. H.: Science and art in preparing tissues embedded in plastic for light microscopy, with special reference to glycol methacrylate, glass knives and sample stains. Stain Technol. 51: 71-97, 1976.

28) Young, R. W.: Cell proliferation and specialization during endochondral osteogenesis in young rats. J. Cell. Biol. 14: 357-370, 1962.

29) Kimmel, D. B. and Jee, W. S. S.: A quantitative histologic analysis of the growing long bone metaphysis. Calcif. Tiss. Int. 32: 113122, 1980.

30) Schenk, R. K., Spiro, D. and Weiner, J.: Cartilage resorption in the tibial epiphyseal plate of growing rats. J. Cell Biol. 34: 275-291, 1967.

31) Schenk, R. K., Wiener, J. and Spiro, D.: Fine structural aspects of vascular invasion of the tibial epiphyseal plate of growing rats. Acta Anat. 69: 1-17, 1968.

32) Kimmel, D. B. and Jee, W. S. S.: Bone cell kinetics during longitudinal bone growth in the rat. Calcif. Tiss. Int. 32: 123-133, 1980.

33) Treuta, J. and Morgan, J. D.: The vascular contribution to osteogenesis. 1. Studies by the injection method. J. Bone Joint Surg. 42B: 97-109, 1960.

34) Treuta, J. and Little, K.: The vascular contribution to osteogenesis. 2. Studies with the electron microscope. J. Bone Joint Surg. 42B: 367-376, 1960.

35) Cameron, D. A.: Erosion of epiphysis of the rat tibia by capillaries. J. Bone Joint Surg. 43B: 590-594, 1961.

36) Irving, M. H.: The blood supply of growth cartilage in young rats. J. Anat. 98: 613639, 1964.

37) Anderson, C. E. and Parker, J.: Invasion and resorption in endochondral ossification. J. Bone Joint Surg. 48A : 899-914, 1966.

38) Schenk, R.: Basic histomorphology and physiology of skeletal growth. In: Treatment of Fractures in Children and Adolescents (Weber, B. G., Burner, C. and Freuler, F., ed.), pp. 3-19, Springer, Berlin, 1980.

39) Kusttner, K. E. and Pauli, B. V.: Vascularity of cartilage. In: Cartilage (Hall, B. K., ed.), vol. 1, pp. 281-312, Academic Press, New York, 1983. 